\title{
KEMAMPUAN PEMERINTAH DAERAH PROVINSI LAMPUNG DALAM MEMBAYAR PINJAMAN DAERAH DI ERA OTONOMI DAERAH
}

\author{
Indrayenti \\ Endang Siswati Prihastuti \\ Fransiska Budiman
}

\begin{abstract}
The purpose of this study was to calculate how much capacity the maximum loan amount area where the Provincial Government of Lampung make loans in accordance with the Government Regulation Number 54 of 2005, and to assess the ability to pay obligations (principal + interest) loan areas do. The hypothesis proposed is the author of Lampung provincial government can borrow to finance its budget deficit area in general accordance with the rules established by the Central Government.

Research methods used are observation, documentation, and interviews. While analysis tools used is the approach that is descriptive quantitative analysis. Based on the results of calculations based on Government Regulation No. 54 Year 2005 on Regional Loan that the Provincial Government of Lampung in 2005-2007 had loans Limit or 60\% general revenue budget the previous year average of Rp.632.461.846.102, - and limits the maximum loan for a period of 5 (five) years, the bank rate by $10 \%$, and $1 \%$ commitment fee can not be done, because the resulting value does not reach the DSCR of 2.5 or more. To achieve the debt service coverage ratio (DSCR) of or equal to 2.5 for a period of 5 (five) years, $10 \%$ interest, and a commitment fee of $1 \%$ loan that can be done only by an average of Rp.342.583.020.438, - or by $36 \%$ of the general acceptance APBDt-1 in 2005-2007.
\end{abstract}

Keywords: Municipal Obligation, Ability to Pay, Regional Autonomy

\section{PENDAHULUAN}

Undang-Undang Nomor 22 Tahun 1999 tentang Pemerintahan Daerah sebagaimana telah dirubah dengan Undang-Undang Nomor 32 Tahun 2004 dan Undang-Undang Nomor 25 Tahun 1999 tentang Perimbangan Keuangan antara Pemerintah Pusat dan Daerah sebagaimana telah dirubah dengan Undang-Undang Nomor 33 Tahun 2004 merupakan landasan utama pelaksanaan desentralisasi di bidang politik, administrasi, dan fiskal dalam rangka mewujudkan pelaksanaan otonomi daerah. Undang-Undang Nomor 32 Tahun 2004 memfokuskan pada pembagian kewenangan dan fungsi antara Pemerintah Pusat dan Pemerintah Daerah, sementara Undang-Undang Nomor 33 Tahun 2004 mengatur tentang pembagian sumber daya keuangan (financial sharing) antara Pemerintah Pusat dan Pemerintah Daerah sebagai konsekuensi logis atas pembagian kewenangan tersebut.

Salah satu isu strategis dalam implementasi otonomi daerah, adalah isu keuangan daerah. Suatu daerah otonom Provinsi akan memiliki kemampuan tinggi untuk mewujudkan visinya, ketika daerah yang bersangkutan selain mempunyai sumber daya manusia yang 
handal, sumber daya alam, tempat yang strategis, serta arah kebijakan dan rencana program yang tepat sasaran, termasuk juga di dalamnya unsur kemampuan keuangan daerah yang cukup memadai. Namun dalam kenyataannya menunjukan bahwa daerah yang mempunyai kemampuan keuangannya terbatas dapat dipastikan akan memerlukan kerja ekstra keras dalam mewujudkan visinya. Provinsi Lampung yang mempunyai luas wilayah 3.528.835 hektar, dan jumlah penduduk pada tahun 2007 sebesar 7.289.767 jiwa tersebar di 8 (delapan) kabupaten dan 2 (dua) kota yaitu masing-masing sebesar seperti dalam tabel 1 seperti berikut ini.

Tabel 1

Jumlah Penduduk Provinsi Lampung. Hasil Sensus, 2007

\begin{tabular}{|ll|c|}
\hline \multicolumn{1}{|c|}{ Kabupaten / Kota } & Jumlah Penduduk \\
\hline 1. Kab Lampung Barat & 381.439 \\
2. Kab Tanggamus & 826.610 \\
3. Kab Lampung Selatan & 1.341 .258 \\
4. Kab Lampung Timur & 936.734 \\
5. Kab Lampung Tengah & 1.160 .221 \\
6. Kab Lampung Utara & 562.314 \\
7. Kab Way Kanan & 362.749 \\
8. Kab Tulang Bawang & 774.265 \\
9. Kota Bandar Lampung & 812.133 \\
10. Kota Metro & 132.044 \\
\hline Jumlah & $\mathbf{7 . 2 8 9 . 7 6 7}$ \\
\hline
\end{tabular}

Sumber: BPS Provinsi Lampung 2007

Oleh sebab itu, di era desentralisasi ini daerah harus benar-benar mampu meningkatkan kemampuan keuangan daerahnya untuk membiayai sumber pembiayaan pembangunan dalam rangka meningkatkan kesejahteraan masyarakat. Dari jumlah penduduk tersebut terdapat penduduk miskin sebesar 2.577.251 jiwa atau 35,08\%.

Tabel 2

Anggaran Pendapatan dan Belanja Daerah Provinsi Lampung 2004 s/d 2007

\begin{tabular}{|c|c|c|c|}
\hline Tahun & Pendapatan & Belanja & Selisih \\
\hline 2004 & 671.553 .124 .983 & 839.196 .065 .759 & 167.642 .940 .776 \\
\hline 2005 & 745.860 .831 .315 & 937.810 .831 .315 & 191.950 .000 .000 \\
\hline 2006 & 1.122 .027 .862 .440 & 1.518 .761 .075 .220 & 396.733 .212 .780 \\
\hline 2007 & 1.277 .182 .832 .400 & $1.615 .808 .213 .266,98$ & $338.625 .380 .866,98$ \\
\hline
\end{tabular}

Sumber: APBD Provinsi Lampung, BPK, 2007

Kalau dilihat dari APBD Provinsi Lampung pada tahun 2007 sebesar Rp1.615.808.213.266,98 sedangkan pendapatan sebesar Rp1.277.182.832.400,- sehingga terjadi defisit anggaran Rp338.625.380.866,98. Defisit anggaran tersebut dialokasikan pada belanja publik yaitu pembangunan pelayanan dasar dan fasilitas umum (pelayanan pendidikan, pelayanan kesehatan, dan pembangunan fasilitas transportasi). Pemerintah Daerah Provinsi Lampung telah memprioritaskan pada pelayanan publik, anggaran belanja publik mempunyai proporsi 70,5\% atau sebesar Rp1.139.144.790.353,22- dari seluruh Anggaran Pendapatan dan Belanja Daerah tahun 2007 sebesar Rp1.615.808.213.266,98. 
Pada umumnya pemerintah daerah sampai dengan saat ini dalam membiayai APBD biasanya masih mengandalkan sumber-sumber Pendapatan Asli Daerah (PAD) yang sudah ada, dan dana perimbangan dari pemerintah pusat yang berupa Dana Alokasi Umum (DAU), Dana Alokasi Khusus (DAK), atau transfer dari pemerintah atasan lainnya untuk membiayai aktivitas pemerintahan, padahal jika kebiasaan seperti ini terus-menerus berlanjut maka kemungkinan besar, pemerintah daerah tersebut hanya akan mampu untuk membiayai belanja aparatur saja dan belanja pelayanan publik akan relatif lebih kecil sehingga untuk mewujudkan kesejahteraan masyarakat sulit tercapai. Untuk mewujudkan visi Provinsi Lampung "Terwujudnya Masyarakat Lampung yang Sejahtera, Bertaqwa, Harmonis, dan Demokratis, serta Menjadi Provinsi Unggulan Berdayasaing di Indonesia" akan sangat lambat perkembangan pembangunan sarana dan prasarana untuk publik (Renstra Provinsi lampung 2004-2009).

Tabel 3

Perbandingan Target PAD dan Realisasi PAD Provinsi Lampung 2004 s/d 2007 (atas dasar harga berlaku)

\begin{tabular}{|c|c|c|c|c|}
\hline No. & Tahun Anggaran & $\begin{array}{c}\text { Target PAD } \\
(\mathbf{R p})\end{array}$ & $\begin{array}{c}\text { Realisasi PAD } \\
(\text { RP) }\end{array}$ & $\boldsymbol{\%}$ \\
\hline 1. & 2004 & 305.117 .936 .425 & $410.682 .087 .702,42$ & 134,60 \\
\hline 2. & 2005 & 346.266 .831 .315 & $549.657 .847 .500,47$ & 158,74 \\
\hline 3. & 2006 & 512.215 .692 .440 & $631.981 .955 .887,68$ & 123,38 \\
\hline 4. & 2007 & 602.552 .662 .400 & $674.693 .661 .673,11$ & 111,97 \\
\hline Rata-rata & & $\mathbf{4 4 1 . 5 3 8 . 2 8 0 . 6 4 5}$ & $\mathbf{5 6 6 . 7 5 3 . 8 8 8 . 1 9 0 , 9 2}$ & $\mathbf{1 3 2 , 1 7}$ \\
\hline
\end{tabular}

Sumber: Realisasi PAD Provinsi Lampung, BPK, 2007

Melihat dari tabel tersebut diatas dari tahun 2004 sampai dengan tahun 2007 pencapaian realisasi rata-rata diatas $100 \%$ yaitu $132,17 \%$, tetapi secara nilai nominal masih belum begitu besar, ini dibuktikan terhadap kontribusi yang diberikan terhadap APBD masih belum signifikan ini dapat dilihat bahwa masih dibawah 50\% dari APBD setiap tahunnya. Ada baiknya pencapaian realisasi tidak mencapai $100 \%$ tetapi nilai nominalnya besar dan memberikan kontribusi terhadap APBD lebih dari 50\%.

Tabel 4

Kontribusi Pendapatan Asli Daerah (PAD) terhadap Anggaran Pendapatan dan Belanja Daerah (APBD) Provinsi Lampung 2004 s/d 2007

\begin{tabular}{|c|c|c|c|c|}
\hline No. & Tahun Anggaran & $\begin{array}{c}\text { APBD } \\
(\mathbf{R p})\end{array}$ & $\begin{array}{c}\text { Realisasi PAD } \\
(\mathbf{R p})\end{array}$ & \% \\
\hline 1. & 2004 & $751.108 .750 .648,50$ & $410.682 .087 .702,42$ & 54,68 \\
\hline 2. & 2005 & $865.194 .609 .741,44$ & $549.657 .847 .500,47$ & 63,53 \\
\hline 3. & 2006 & $1.341 .056 .664 .937,51$ & $631.981 .955 .887,68$ & 47,13 \\
\hline 4. & 2007 & $1.532 .401 .692 .047,27$ & $674.693 .661 .673,11$ & 44,03 \\
\hline Rata-rata & & $\mathbf{1 . 1 2 2 . 4 4 0 . 4 2 9 . 3 4 3 , 6 8}$ & $\mathbf{5 6 6 . 7 5 3 . 8 8 8 . 1 9 0 , 9 2}$ & $\mathbf{5 2 , 3 4}$ \\
\hline
\end{tabular}

Sumber: Perhitungan APBD Provinsi Lampung (data diolah)

Melihat kontribusi Pendapatan Asli Daerah (PAD) terhadap Anggaran Pendapatan dan Belanja Daerah (APBD) Provinsi Lampung yang rata-rata 52,34\% oleh karenanya pemerintah daerah harus berani mengambil langkah-langkah untuk mencari sumber-sumber yang lain seperti pinjaman daerah atau menerbitkan obligasi daerah yang nantinya dapat 
dipergunakan untuk menambah sumber penerimaan pembiayaan pembangunan. Dalam reformasi anggaran juga terdapat perubahan yang sangat mendasar terutama dalam Peraturan Pemerintah Nomor 58 tahun 2005 tentang Pengelolaan Keuangan Daerah terdapat perubahan yang mendasar ditabulasikan sebagai berikut:

Tabel 5

Perubahan Anggaran Berimbang ke Anggaran Kinerja Menurut PP No 58 Tahun 2005 Perubahan yang Mendasar

\begin{tabular}{|c|c|}
\hline Lama & Baru \\
\hline $\begin{array}{l}\text { 1. Anggaran Tadisional } \\
\text { 2. Sistem Anggaran Berimbang \& } \\
\text { Dinamis } \\
\text { 3. APBD terdiri dari Pendapatan dan } \\
\text { Belanja. } \\
\text { 4. APBD dibagi Belanja Rutin dan } \\
\text { Belanja Pembangunan. } \\
\text { 5. Tidak dipisahkan ke Belanja } \\
\text { Aparatur dan Belanja Publik. } \\
\text { 6. Pinjaman sebagai komponen } \\
\text { pendapatan. }\end{array}$ & $\begin{array}{l}\text { 1. Anggaran Kinerja. } \\
\text { 2. Sistem Anggaran Surplus/Defisit. } \\
\text { 3. APBD terdiri dari Pendapatan, } \\
\text { Belanja, dan Pembiayaan. } \\
\text { 4. APBD dibagi BAU, BOP, dan } \\
\text { Belanja Modal, BBHBK, dan } \\
\text { BTT. } \\
\text { 5. Dipisahkan ke Belanja Publik } \\
\text { dan Belanja Aparatur. } \\
\text { 6. Pinjaman sebagai komponen } \\
\text { pembiayaan. }\end{array}$ \\
\hline
\end{tabular}

Sumber: Peraturan Pemerintah No. 58 Tahun 2005

\section{Telaah Literatur dan Pengembangan Hipotesis}

\section{Pengertian Pinjaman Daerah}

Menurut Peraturan Pemerintah Nomor 54 Tahun 2005 tentang Pinjaman Daerah :

"Pinjaman Daerah adalah semua transakasi yang mengakibatkan Daerah menerima sejumlah uang atau menerima manfaat yang bernilai uang dari pihak lain sehingga Daerah tersebut dibebani kewajiban untuk membayar kembali." Menurut Ahmad Yani, S.H., M.M, Ak (2002, 198), Pinjaman Daerah merupakan salah satu sumber penerimaan Daerah dalam rangka pelaksanaan Desentralisasi, yang dicatat dan dikelola dalam Anggaran Pendapatan dan Belanja Daerah. Dana Pinjaman merupakan pelengkap dari sumber-sumber penerimaan Daerah yang ada dan ditujukan untuk membiayai pengadaan prasarana Daerah atau harta tetap lain yang berkaitan dengan kegiatan yang bersifat meningkatkan penerimaan yang dapat digunakan untuk mengembalikan pinjaman, serta memberikan manfaat bagi pelayanan masyarakat.

Pinjaman Daerah perlu disesuaikan dengan kemampuan Daerah, karena dapat menimbulkan beban Anggaran Pendapatan dan Belanja Daerah tahun-tahun berikutnya yang cukup berat sehingga perlu didukung dengan keterampilan perangkat Daerah dalam mengelola Pinjaman Daerah. Untuk meningkatkan kemampuan obyektif dan disiplin Pemerintah Daerah dalam melaksanakan pengembalian pinjaman, maka diperlukan kecermatan dan kehati-hatian dalam pengelolaan Pinjaman Daerah.

\section{Persyaratan Pinjaman Daerah}

Pemerintah Daerah wajib memenuhi persyaratan sebagai berikut :

1. Jumlah sisa Pinjaman Daerah ditambah jumlah pinjaman yang akan ditarik tidak melebihi $75 \%$ dari jumlah penerimaan umum APBD tahun sebelumnya. 
2. Rasio proyeksi kemampuan keuangan daerah untuk mengembalikan pinjaman paling sedikit 2,5.

$$
D S C R=\frac{(P A D+(D B H-D B H D R)+D A U)-\text { Belanja Wajib }}{\text { Angsuran Pokok Pinjaman }+ \text { Bunga }+ \text { Biaya Lain }} \geq 2,5
$$

Keterangan :

DSCR = Debt Service Coverage Ratio atau Rasio Kemampuan

Membayar Kembali Pinjaman.

PAD $\quad=$ Pendapatan Asli Daerah

DAU = Dana Alokasi Umum

$\mathrm{DBH} \quad=$ Dana Bagi Hasil

DBHDR = Dana Bagi Hasil Dana Reboisasi

3. Tidak mempunyai tunggakan atas pengembalian pinjaman yang berasal dari Pemerintah.

4. Mendapatkan persetujuan DPRD.

\section{Pembayaran Pinjaman Daerah}

Menurut Peraturan Pemerintah Nomor 54 Tahun 2005, sesuai dengan definisi pinjaman daerah, bahwa daerah mempunyai kewajiban untuk membayar kembali atas pinjaman tersebut. Adapun prosedur pembayaran kembali pinjaman daerah sebagai berikut :

1. Kewajiban pembayaran kembali Pinjaman Daerah yang jatuh tempo wajib dianggarkan dalam APBD dan direalisasikan/dibayarkan pada tahun anggaran yang bersangkutan.

2. Pembayaran kembali Pinjaman Daerah dari Pemerintah, dilakukan dalam mata uang sesuai yang ditetapkan dalam perjanjian Pinjaman antara Menteri Keuangan dan kepala Daerah.

3. Dalam hal Daerah tidak memenuhi kewajiban membayar pinjamannya kepada Pemerintah, kewajiban membayar pinjaman tersebut diperhitungkan dengan DAU dan/atau Dana Bagi Hasil dari Penerimaan Negara yang menjadi hak Daerah tersebut.

\section{Pelaporan dan Sanksi Pinjaman Daerah}

Menurut Peraturan Pemerintah Nomor 54 Tahun 2005 untuk ketertiban dan transparansi pinjaman daerah diperlukan pembukuan dan pelaporan yang tertib sebagai berikut :

1. Semua penerimaan dan kewajiban dalam rangka Pinjaman Daerah dicantumkan dalam APBD dan dibukukan sesuai dengan Standar Akuntansi Pemerintah.

2. Keterangan yang memuat semua pinjaman jangka menengah dan jangka panjang wajib dituangkan dalam lampiran dari dokumen APBD.

3. Setiap perjanjian pinjaman yang dilakukan oleh Daerah merupakan dokumen publik dan diumumkan dalam Lembaran Daerah.

4. Pemerintah Daerah wajib melaporkan posisi kumulatif pinjaman dan kewajiban pinjaman kepada Menteri Keuangan dan Menteri Dalam Negeri setiap semester dalam tahun anggaran berjalan. Dalam hal Daerah tidak menyampaikan laporan tersebut maka Menteri Keuangan dapat menunda penyaluran Dana Perimbangan.

\section{Instrumen Pengelolaan Keuangan Daerah}

Menurut Mardiasmo (2004:6) anggaran kinerja harus dilihat secara utuh, meliputi multisystem yang harus bekerja secara komprehensif yang terdiri dari atas sistem perencanaan, sisteem pelaksanaan, sistem pelaporan, dan sistem pertanggungjawaban dan evaluasi. Agar sistem pengelolaan tersebut bekerja dengan baik perlu didukung oleh 
instrumen pengelolaan keuangan daerah yang pada dasarnya dibagi dalam kelompok besar sebagai berikut :

1. Instrumen Perencanaan

Tersedianya dokumen perencanaan anggaran.

Tersedianya dokumen untuk proses penyusunan anggaran (tahunan).

Peranan DPRD pada tahap perencanaan.

2. Instrumen Pelaksanaan

Tersedianya pedoman sistem akuntansi keuangan daerah (SAKD).

Tersedianya indikator kinerja keuangan dan non keuangan (Public Sector Scorecard)

Adanya proses monitoring dari masing-masing kepala Kantor/Dinas

Peranan Badan Pengawasan Keuangan Daerah (APIP)

Peranan DPRD pada tahap pelaksanaan

3. Instrumen Pelaporan

Tersedianya laporan Keuangan dari hasil SAKD

Tersedianya Laporan Tambahan

Trsedianya Lampiran atas Laporan Keuangan

4. Instrumen Pertanggungjawaban dan Evaluasi

Dilakukannya Audit oleh Eksternal Auditor (BPK) terhadap Laporan Keuangan

Hubungan antara internal Auditor dan Eksternal Auditor

Peranan DPRD pada tahap pertanggungjawaban dan evaluasi

Partisipasi elemen masyarakat sebagai social control.

\section{Kerangka Teoritis}

Pemerintah daerah dalam penetapan APBD setiap tahun yang mengacu pada PP Nomor 58 Tahun 2005 tentang Pengelolaan Keuangan Daerah menganut Anggaran Surplus/Defisit.

Apabila pendapatan lebih besar dibanding dengan belanja maka terjadi surplus pendapatan. Surplus pendapatan harus dikeluarkan ke dalam pos sebagai berikut:

1. Transfer ke dana cadangan

2. Penyertaan modal

3. Membayar utang pokok yang jatuh tempo

4. Sisa lebih perhitungan anggaran tahun berkenaan.

Selanjutnya kalau belanja lebih besar dari pendapatan, maka terjadilah defisit anggaran. Anggaran yang defisit ini perlu dicarikan solusi untuk menutupnya. Untuk menutupi defisit anggaran tersebut terdapat beberapa langkah yaitu dengan menggunakan penerimaan daerah dalam komponen pembiayaan yaitu:

1. Sisa lebih perhitungan anggaran tahun lalu

2. Transfer dari dana cadangan

3. Menjual asset daerah

4. Mencari pinjaman daerah atau menjual obligasi daerah.

Sebelum melakukan pinjaman daerah perlu melakukan analisis kemampuan keuangan daerah yang mengacu pada ketentuan dasar mengenai sumber penghasilan dan pembiayaan daerah. Sebagaimana yang telah ditetapkan dalam Undang-Undang Nomor 32 Tahun 2004 tentang Pemerintah Daerah dan Undang-Undang Nomor 33 Tahun 2004 tentang Perimbangan Keuangan Antara Pemerintah Pusat dan Pemerintah Daerah disebutkan bahwa sumber pendapatan daerah terdiri dari: 1. Pendapatan Asli Daerah, yaitu: a) Hasil pajak daerah; b) Hasil retribusi daerah; c) Hasil perusahaan milik daerah, hasil pengelolaan kekayaan daerah 
yang dipisahkan; 2. Dana perimbangan; 3. Pinjaman Daerah; dan 4. Lain-lain pendapatn daerah yang sah.

Berdasarkan kedua Undang-Undang tersebut menyatakan bahwa pinjaman daerah merupakan sumber keuangan daerah yang dapat dijadikan salah satu alternatif bagi pemerintah daerah untuk menutupi kekurangan dana untuk membiayai pembangunan daerah.

Dalam penelitian ini mempergunakan cara untuk menutup defisit anggaran dengan menggunakan pinjaman daerah. Supaya tidak terjadi penyimpangan dalam melakukan pinjaman daerah harus mengacu pada Peraturan Pemerintah Republik Indonesia Nomor 58 tahun 2005 tentang Pinjaman Daerah.

\section{METODOLOGI PENELITIAN}

\section{Obyek Penelitian}

Penelitian ini dilaksanakan di Pemerintah Daerah Provinsi Lampung, dalam penelitian ini untuk mendapatkan data dilakukan dengan cara mengumpulkan, mengamati, dan mengelolah data sekunder runtut waktu (time series) tahunan dari tahun 2004-2007 yang meliputi Anggaran Pendapatan Belanja Daerah (APBD) yang terdiri dari Pendapatan Asli Daerah (PAD), bagian bagi hasil pajak/bukan pajak, dana alokasi umum, belanja rutin dan belanja pembangunan atau belanja aparatur dan belanja publik Pemerintah Daerah Provinsi Lampung yang dikumpulkan dari Dinas Pendapatan Daerah, Biro Keuangan Sekretariat Pemerintah Daerah Provinsi Lampung, Badan Pemeriksaan Keuangan Provinsi Lampung, dan badan Pusat Statistik Provinsi Lampung serta studi literatur/pustaka yang berkaitan dengan pelaksanaan penelitian ini.

\section{Pengumpulan Data}

Data-data yang digunakan dalam penelitian adalah: Data sekunder, yaitu data yang dikumpulkan oleh pihak lain yaitu Dinas Pendapatan Daerah, Biro Keuangan Sekretariat Pemerintah Daerah Provinsi Lampung, Badan Pemeriksaan Keuangan Provinsi Lampung, dan badan Pusat Statistik Provinsi Lampung, dan telah didokumentasikan sehingga dapat digunakan oleh peneliti, serta data yang didapat dari membaca dan meneliti buku-buku, literatur-literatur, artikel-artikel, dan makalah-makalah yang berhubungan dengan topik penelitian.

\section{Definisi Operasional Variabel}

1. Kemampuan keuangan daerah adalah merupakan bagaimana daerah dapat menyediakan dan mengatur sumber daya yang ada di daerah tersebut, sehingga mampu untuk mendanai kegiatan pemerintah daerah yang melakukan pelayanan kepada masyarakat.

2. Keuangan daerah adalah semua hak dan kewajiban daerah dalam rangka penyelenggaraan Pemerintahan Daerah yang dapat dinilai dengan uang termasuk didalamnya segala bentuk kekayaan yang berhubungan dengan hak dan kewajiban daerah tersebut.

3. Penerimaan daerah adalah uang yang masuk ke kas daerah.

4. Anggaran Pendapatan dan Belanja Daerah (APBD) adalah rencana keuangan tahunan Pemerintah Daerah yang dibahas dan disetujui bersama oleh pemerintah Daerah dan DPRD, dan ditetapkan dengan peraturan daerah.

5. Pendapatan Asli Daerah (PAD) adalah penerimaan yang diperoleh daerah dari sumbersumber dalam wilayahnya sendiri yang dipungut berdasarkan peraturan daerah sesuai 
dengan peraturan perundang-undang yang berlaku. Antara lain; hasil pajak daerah, hasil retribusi daerah, hasil perusahaan milik daerah dan hasil pengelolaan kekayaan daerah lainnya yang dipisahkan, serta lain-lain pendapatan asli daerah yang sah.

6. Belanja Daerah adalah kewajiban pemerintah yang diakui sebagai pengurangan nilai kekayaan bersih. Belanja daerah dibedakan menjadi 2 (dua) yaitu belanja aparatur daerah dan pelayanan publik. Belanja aparatur daerah terdiri dari belanja administrasi umum dan belanja operasi dan pemeliharaan. Dan belanja pelayanan publik terdiri dari belanja administrasi umum, belanja operasional dan pemeliharaan, belanja modal, belanja bagi hasil, belanja bantuan keuangan dan belanja tidak terduga.

7. Pinjaman daerah adalah semua transaksi yang mengakibatkan daerah menerima sejumlah uang atau menerima manfaat yang bernilai uang dari pihak lain sehingga daerah dibebani kewajiban untuk membayar kembali.

8. Dana Alokasi Umum (DAU) adalah merupakan salah satu jenis penerimaan daerah yang bersumber dari Anggaran Pendapatan dan Belanja Negara (APBN), yang dialokasikan ke daerah provinsi atau Kabupaten /kota dengan tujuan untuk pemerataan keuangan daerah yang digunakan untuk pembiayaan pelaksanaan desentralisasi fiscal.

\section{Metode Analisis}

Mengukur dan menentukan variable yang akan diteliti menggunakan pendekatan analisis kuantitatif yang bersifat deskriptif seperti jumlah maksimum pinjaman dan kemampuan tingkat pengembalian pinjaman Debt Service Coverage Ratio (DSCR) sesuai dengan Peraturan Pemerintah Nomor 54 Tahun 2005 tentang Pinjaman Daerah dengan formulasi sebagai berikut:

\section{Batas Maksimum Pinjaman Daerah}

Untuk mengetahui seberapa besar yang diperbolehkan suatu pemerintah daerah apabila ingin melakukan pinjaman, menurut kemampuan yang didukung oleh data-data yang dimiliki sampai saat ini dapat dihitung dengan rumus yang berdasarkan Peraturan Pemerintah Nomor 54 Tahun 2004 tentang Pinjaman Daerah sebagai berikut :

NetPinjaman Pemerintah Daerah $=$ Total Pinjaman Pemerintah Daerah - Piutang kepada Pemerintah Pusat dan/atau Piutang kepada Pemerintah Daerah lainnya.

Batas maksimal kumulatif pinjaman Pemerintah Daerah tidak boleh melebihi $60 \%$ (enam puluh persen) dari Produk Domestik Bruto tahun yang bersangkutan.

\section{Kemampuan Pengembalian Pinjaman}

Keterangan :

$$
D S C R=\frac{(P A D+(D B H-D B H D R)+D A U)-\text { Belanja Wajib }}{\text { Angsuran Pokok Pinjaman }+ \text { Bunga }+ \text { Biaya Lain }} \geq 2,5
$$

DSCR = Debt Service Coverage Ratio atau Rasio Kemampuan Membayar Kembali Pinjaman;

PAD $\quad=$ Pendapatan Asli Daerah;

DAU $\quad=$ Dana Alokasi Umum;

DBH $\quad=$ Dana Bagi Hasil;

DBHDR = Dana Bagi Hasil Dana Reboisasi. 


\section{Future Value Anuity}

Alat analisis ini yang dipergunakan untuk menentukan jumlah pinjaman daerah berdasarkan kemampuan keuangan yang mempertimbangkan periode waktu, masa tenggang dan bunga pinjaman. Untuk menentukan jumlah pinjaman daerah dapat diformulasikan sebagai berikut:

$$
P D=a\left(\frac{1}{r}-\frac{1}{r(1+r)^{n}}\right)
$$

Keterangan :

$$
\begin{aligned}
& \text { PD = Pinjaman Daerah } \\
& \mathrm{a} \quad=\text { Angsuran Pinjaman } \\
& \mathrm{r}=\text { Suku bunga } \\
& \mathrm{n} \quad=\text { Jangka Waktu Pinjaman }
\end{aligned}
$$

\section{Present Value Anuity}

Alat analisis ini yang dipergunakan untuk menentukan jumlah pinjaman daerah dari suatu nilai yang akan diterima atau harus dibayar di masa yang akan datang berdasarkan kemampuan keuangan yang mempertimbangkan periode waktu, masa tenggang dan bunga pinjaman. Untuk menentukan jumlah pinjaman daerah dapat diformulasikan sebagai berikut :

$P D=a \times \frac{\left(1-\left(\frac{1}{(1+r)^{n}}\right)\right.}{r}$

Keterangan :

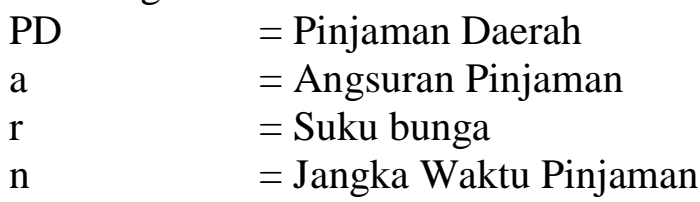

\section{HASIL DAN PEMBAHASAN}

\section{Penerimaan Daerah tahun 2004 - 2007}

Sumber penerimaan umum Anggaran Pendapatan dan Belanja Daerah (APBS) Pemerintah Daerah Provinsi Lampung yang terdiri dari pendapatan asli daerah, bagi hasil pajak/bukan pajak, dana alokasi umum secara rinci dari tahun anggaran 2004-2007 dapat dilihat pada Tabel 6 .

Tabel 6

Penerimaan Umum Daerah Pemerintah Daerah Provinsi Lampung dari PAD, Bagi Hasil

Pajak/Bukan Pajak,

Dana Alokasi Umum, 2004 s/d 2007

\begin{tabular}{|c|c|c|c|c|}
\hline $\begin{array}{c}\text { Tahun } \\
\text { Anggaran }\end{array}$ & $\begin{array}{c}\text { PAD } \\
(\mathbf{R p})\end{array}$ & $\begin{array}{c}\text { BHP/BHBP } \\
(\mathbf{R p})\end{array}$ & $\begin{array}{c}\text { DAU } \\
(\mathbf{R p})\end{array}$ & $\begin{array}{c}\text { Total } \\
\text { Penerimaan }\end{array}$ \\
\hline 2004 & 410.682 .087 .702 & 123.953 .131 .994 & 286.822 .000 .000 & 821.457 .219 .696 \\
\hline 2005 & 549.657 .847 .500 & 185.410 .330 .288 & 310.835 .000 .000 & 1.045 .903 .177 .788 \\
\hline 2006 & 631.981 .955 .887 & 202.068 .877 .137 & 460.898 .000 .000 & 1.294 .948 .833 .024 \\
\hline 2007 & 674.693 .661 .673 & 177.128 .795 .491 & 509.656 .000 .000 & 1.361 .478 .457 .164 \\
\hline
\end{tabular}


Dari Tabel tersebut dapat dipahami bahwa penerimaan umum Pemerintah Daerah Provinsi Lampung dari tahun anggaran 2004 sampai dengan tahun anggaran 2007 yang terdiri dari pendapatan asli daerah, bagi hasil pajak/bukan pajak, serta dana alokasi umum mengalami peningkatan setiap tahunnya yaitu pada tahun 2004 sebesar Rp.821.457.219.696,menjadi pada tahun 2007 sebesar Rp1.361.478.457.164,- atau sebesar 166\%.

Untuk peningkatan penerimaan umum daerah yang sebaiknya lebih diprioritaskan oleh pemerintah daerah adalah penerimaan umum yang bersumber dari pendapatan asli daerah, karena pendapatan asli daerah ini tidak bergantung dari pemerintah pusat tetap berdasarkan dari kreasi dan kemampuan daerahnya baik dari segi sumber daya alam maupun dari sumber daya manusianya sebagai pelaku utama konsep pembangunan yang berkelajutan. Kalau dilihat dari peningkatan pendapatan asli daerah dari tahun 2004 sampai dengan tahun 2007 cukup tinggi yaitu Rp.410.682.087.702,- menjadi Rp.674.693.661.673,- atau 164\%, ini memberikan indikasi bahwa pendapatan asli daerah masih dapat ditingkatkan lagi di masa yang akan datang dengan cara mencari sumber-sumber pendapatan asli daerah, yang selama ini belum tergali atau meningkatkan target yang selama ini masih rendah sehingga pencapaian realisasi melampaui target yang ditetapkan walaupun nilai nominalnya masih relatif kecil.

\section{Belanja Wajib Daerah tahun 2004 - 2007}

Belanja wajib adalah belanja yang menjadi prioritas utama dan tidak dapat dihindari keberadaannya dalam setiap tahun anggaran berjalan. Dalam penelitian ini diasumsikan bahwa belanja wajib dibedakan menjadi 2 (dua) yaitu belanja aparatur dan belanja publik.

Tabel 7

Belanja Wajib Pemerintah Daerah Provinsi Lampung 2004 s/d 2007

\begin{tabular}{|c|c|c|c|}
\hline $\begin{array}{c}\text { Tahun } \\
\text { Anggaran }\end{array}$ & $\begin{array}{c}\text { Belanja Aparatur } \\
(\mathbf{R p})\end{array}$ & $\begin{array}{c}\text { Belanja Publik } \\
(\mathbf{R p})\end{array}$ & $\begin{array}{c}\text { Belanja Wajib } \\
(\mathbf{R p})\end{array}$ \\
\hline 2004 & 206.501 .926 .878 & 544.606 .823 .770 & 751.108 .750 .648 \\
\hline 2005 & 571.940 .377 .800 & 120.864 .554 .941 & 692.804 .932 .741 \\
\hline 2006 & 347.813 .375 .558 & 993.243 .289 .378 & 1.341 .056 .664 .936 \\
\hline 2007 & 934.883 .856 .461 & 296.527 .356 .806 & 1.231 .411 .213 .267 \\
\hline Rata-rata & $515.284 .884 .174,25$ & $488.810 .506 .223,75$ & 1.004 .095 .394 .898 \\
\hline
\end{tabular}

Memperhatikan Tabel 7 di atas bahwa belanja wajib dari tahun anggaran 2004-2007 cenderung berfluktuasi. Belanja wajib terendah terjadi pada tahun 2005 dan belanja wajib tertinggi terjadi pada tahun 2006. 


\section{Batas Maksimum Pinjaman (BMP) tahun 2004 - 2007}

Tabel 8

Batas Maksimum Pinjaman Pemerintah Daerah Provinsi Lampung 2004 s/d 2007

\begin{tabular}{|c|c|c|c|}
\hline $\begin{array}{c}\text { Tahun } \\
\text { Anggaran }\end{array}$ & $\begin{array}{c}\text { Penerimaan Umum } \\
\text { APBD } \\
\text { (Rp) }\end{array}$ & $\begin{array}{c}\text { Batas Pinjaman } \\
\mathbf{0 . 6 0} \text { x APBDt-1 } \\
(\mathbf{R p})\end{array}$ & $\begin{array}{c}\text { BMP } \\
\text { (Rp) }\end{array}$ \\
\hline 2004 & 821.457 .219 .696 & - & - \\
\hline 2005 & 1.045 .903 .177 .788 & 492.874 .331 .818 & 492.874 .331 .818 \\
\hline 2006 & 1.294 .948 .833 .024 & 627.541 .906 .673 & 627.541 .906 .673 \\
\hline 2007 & 1.361 .478 .457 .164 & 776.969 .299 .815 & 776.969 .299 .815 \\
\hline Rata-rata & 1.130 .946 .921 .918 & 632.461 .846 .102 & 632.461 .846 .102 \\
\hline
\end{tabular}

Berdasarkan penerimaan umum Pemerintah Daerah Provinsi Lampung dapat diketahui berapa kemampuan batas maksimum pinjaman yang dapat dilakukan. Sesuai dengan Peraturan Pemerintah Nomor 54 Tahun 2005 tentang Pinjaman Daerah, batas maksimal kumulatif pinjaman Pemerintah Daerah tidak boleh melebihi 60\% (enam puluh persen) dari jumlah penerimaan umum tahun sebelumnya. Penerimaan umum Anggaran Pendapatan dan Belanja Daerah (APBD) yang dimaksudkan disini adalah seluruh penerimaan APBD pada tahun tertentu tidak termasuk penerimaan dana alokasi khusus, dana darurat, penerimaan pinjaman yang lama, dan penerimaan lain yang penggunaannya dibatasi untuk membiayai pengeluaran tertentu.

Besarnya penerimaan umum Pemerintah Daerah Provinsi Lampung pada tahun 2004 sampai dengan tahun anggaran 2007 terus mengalami peningkatan setiap tahunnya dapat dilihat dalam tabel 8.Pada Tabel 8 dapat dilihat bahwa batas maksimum pinjaman Pemerintah Daerah Provinsi Lampung dari tahun 2004 sampai dengan tahuh 2007 terus mengalami peningkatan dari Rp492.874.331.818,- menjadi Rp.776.969.299.815,-. Apabila Pemerintah Daerah Provinsi Lampung akan melakukan pinjaman tidak diperkenankan melebihi batas maksimum pinjaman tersebut, tetapi kalau lebih kecil dari batas itu akan lebih baik, tentunya harus disesuaikan dengan nilai debt service coverage ratio (DSCR). Apabila nilai debt service coverage ratio (DSCR) lebih kecil dari 2,5, maka besar pinjaman harus diturunkan dari batas maksimum pinjaman, sehingga nilai debt service ratio (DSCR) yang didapat minimal lebih besar atau sama dengan 2,5.

\section{Debt Service Coverage Ratio (DSCR) tahun 2004 - 2007}

Untuk menghitung debt service coverage ratio (DSCR) dapat dilakukan dengan mencari selisih penerimaan umum daerah dikurangi dengan belanja wajib kemudian hasilnya dibagi dengan angsuran pokok, bunga pinjaman serta biaya lain atau biaya komitmen jika belum pernah melakukan pinjaman sebelumnya. 
Tabel 9

Kemampuan Keuangan Pemerintah Daerah Provinsi Lampung di Dalam Melakukan Pinjaman Daerah.

2004 s/d 2007

\begin{tabular}{|c|c|c|c|c|c|c|}
\hline $\begin{array}{c}\text { Tahun } \\
\text { Anggaran }\end{array}$ & $\begin{array}{c}\text { Total Penerimaan } \\
(\mathbf{R p})\end{array}$ & $\begin{array}{c}\text { Belanja Wajib } \\
(\mathbf{R p})\end{array}$ & $\begin{array}{c}\text { Dana Netto } \\
(\mathbf{R p})\end{array}$ & $\begin{array}{c}\text { Besar Pinjaman } \\
(\mathbf{R p})\end{array}$ & $\begin{array}{c}\text { Angsuran } \\
(\mathbf{R p})\end{array}$ & $\begin{array}{c}\text { DSC } \\
\text { R }\end{array}$ \\
\hline 2005 & 1.045 .903 .177 .788 & 692.804 .932 .741 & 353.098 .245 .047 & 492.874 .331 .818 & 133.353 .444 .756 & 2,65 \\
\hline 2006 & 1.294 .948 .833 .024 & 1.341 .056 .664 .936 & $(46.107 .831 .912)$ & 627.541 .906 .673 & 169.789 .476 .914 & $-0,27$ \\
\hline 2007 & 1.361 .478 .457 .164 & 1.231 .411 .213 .267 & 130.067 .443 .897 & 776.969 .299 .815 & 210.218 .966 .400 & 0,76 \\
\hline Rata-rata & 1.234 .110 .155 .992 & 1.088 .424 .270 .315 & 145.685 .952 .344 & 632.461 .846 .102 & 171.120 .629 .357 & 1,05 \\
\hline
\end{tabular}

Dari hasil perhitungan DSCR perbandingan dana netto dengan besar angsuran didapat DSCR pada tahun 2005, 2006, 2007 nilainya masih dibawah nilai batas minimal DSCR 2,5 yaitu rata-rata DSCR 1,05 artinya bahwa Pemerintah Daerah Provinsi Lampung tidak mampu melakukan pinjaman maksimum sebesar $0.60 \leq$ APBDt-1 sesuai dengan PP Nomor 54 Tahun 2005 tentang Pinjaman Daerah, dengan jangka waktu pinjaman, tingkat suku bunga bank dan biaya komitmen diasumsikan 1) Lama Pinjaman 5 tahun; 2) Bunga Bank 10\% per tahun; dan Biaya Komitmen 1\%. Untuk tahun 2005-2007 pinjaman yang dapat dilakukan harus lebih kecil dari nilai maksimum pinjaman sehingga mencapai nilai DSCR sama atau lebih besar dari 2,5. Apabila diambil rata-rata debt service coverage ratio (DSCR) masih jauh dari nilai minimal yang ditentukan oleh Peraturan Pemerintah Nomor 54 Tahun 2005 tentang Pinjaman Daerah yaitu minimal atau sama dengan 2,5.

Untuk menentukan batas kemampuan pinjaman yang dapat dilakukan Pemerintah Daerah Provinsi Lampung dengan memperhitungkan besarnya dana netto dan niali debt service coverage ratio (DSCR) sebesar 2,5 dengan asumsi lama pinjaman 5 tahun, suku bunga bank $10 \%$, dan biaya komitmen $1 \%$ dapat dicari besarnya pokok pinjaman seperti dalam tabel 10 .

Tabel 10

Pinjaman yang Dapat Dilakukan

(Lama Pinjaman 5 tahun, Bunga Bank 10\%, Biaya Komitmen 1\%) 2005-2007

\begin{tabular}{|c|c|c|c|c|c|}
\hline Tahun & $\begin{array}{c}\text { Dana Netto } \\
\text { (Rp) }\end{array}$ & DSCR & $\begin{array}{c}\text { Besar Pokok } \\
\text { Pinjaman (Rp) }\end{array}$ & APBDt-1 & \% \\
\hline 2005 & 353.098 .245 .047 & 2,5 & 492.874 .331 .818 & 1.045 .903 .177 .788 & 47 \\
\hline 2006 & $(46.107 .831 .912)$ & 2,5 & - & 1.294 .948 .833 .024 & - \\
\hline 2007 & 130.067 .443 .897 & 2,5 & 192.291 .709 .058 & 1.361 .478 .457 .164 & 25 \\
\hline Rata-rata & $\mathbf{1 4 5 . 6 8 5 . 9 5 2 . 3 4 4}$ & $\mathbf{2 , 5}$ & $\mathbf{3 4 2 . 5 8 3 . 0 2 0 . 4 3 8}$ & $\mathbf{1 . 2 3 4 . 1 1 0 . 1 5 5 . 9 9 2}$ & $\mathbf{3 6}$ \\
\hline
\end{tabular}

Setelah diadakan perhitungan pinjaman Pemerintah Daerah Provinsi Lampung dengan dana netto yang tersedia pada tahun 2005 sebesar 42\%, tahun 2006 sebesar 0\%, dan tahun 2007 sebesar 25\% dari penerimaan umum APBDt-1. Setelah diadakan perhitungan kemampunan keuangan yang didukung dengan dana neto batas maksimum pinjaman sebesar $60 \%$ dari penerimaan umum daerah belum tentu dapat dilakukan. Dengan ketentuan jangka waktu pinjaman, tingkat suku bunga bank dan biaya komitment sudah pasti. Dari simulasi 
yang dilakukan, variable-variabel yang sangat besar mempengaruhi penurunan nilai debt service coverage ratio (DSCR) adalah tingkat suku bunga bank, setiap suku bunga dinaikkan akan mengakibatkan penurunan nilai DSCR seperti yang ditabulasikan pada tabel 11 .

Tabel 11

Perubahan Nilai DSCR apabila Variabel

(Periode Pinjaman, Suku Bunga, dan Biaya Komitmen) dinaikkan masing-masing $20 \%$ dari 5 tahun, $10 \%$, dan $1 \%$

\begin{tabular}{|c|c|c|c|c|c|c|}
\hline $\begin{array}{c}\text { Tahun } \\
\text { Anggaran }\end{array}$ & $\begin{array}{c}\text { Total Penerimaan } \\
(\mathbf{R p})\end{array}$ & $\begin{array}{c}\text { Belanja Wajib } \\
(\mathbf{R p})\end{array}$ & $\begin{array}{c}\text { Dana Netto } \\
(\mathbf{R p})\end{array}$ & $\begin{array}{c}\text { Besar Pinjaman } \\
(\mathbf{R p})\end{array}$ & $\begin{array}{c}\text { Angsuran } \\
(\mathbf{R p})\end{array}$ & DSCR \\
\hline 2005 & 1.045 .903 .177 .788 & 692.804 .932 .741 & 353.098 .245 .047 & 492.874 .331 .818 & 123.280 .223 .066 & 2,9 \\
\hline 2006 & 1.294 .948 .833 .024 & 1.341 .056 .664 .936 & $(46.107 .831 .912)$ & 627.541 .906 .673 & 156.963 .958 .647 & $-0,29$ \\
\hline 2007 & 1.361 .478 .457 .164 & 1.231 .411 .213 .267 & 130.067 .443 .897 & 776.969 .299 .815 & 194.339 .494 .701 & 0,67 \\
\hline Rata-rata & $\mathbf{1 . 2 3 4 . 1 1 0 . 1 5 5 . 9 9 2}$ & $\mathbf{1 . 0 8 8 . 4 2 4 . 2 7 0 . 3 1 5}$ & $\mathbf{1 4 5 . 6 8 5 . 9 5 2 . 3 4 4}$ & $\mathbf{6 3 2 . 4 6 1 . 8 4 6 . 1 0 2}$ & $\mathbf{1 5 8 . 1 9 4 . 5 5 8 . 8 0 5}$ & $\mathbf{1 , 1}$ \\
\hline
\end{tabular}

Dari simulasi tabel diatas dapat dilihat bahwa debt service coverage ratio (DSCR) sangat dipengaruhi oleh periode lama pinjaman dan tingkat suku bunga. Dari tabel diatas dapat dilihat bahwa DSCR dari tahun 2005, 2006, dan 2007 nilainya masih di bawah nilai batas minimum DSCR sebesar 2,5 yaitu rata-rata DSCR 1,1, artinya bahwa Pemerintah Daerah Provinsi Lampung tidak mampu melakukan pinjaman maksimum sebesar $0.60 \leq$ APBDt-1 sesuai dengan PP Nomor 54 Tahun 2005 tentang Pinjaman Daerah, dengan jangka waktu pinjaman, tingkat suku bunga bank dan biaya komitmen diasumsikan sebesar 6 tahun, $12 \%$, dan $1 \%$. bank dan biaya komitmen diasumsikan sebesar 6 tahun, PP Nomor 54 Tahun 2005 tentang Pinjaman Daerah, dengan jangka waktu pinjaman, tingkat suku bunga bank dan biaya komitmen diasumsikan sebesar 6 tahun, $12 \%$, dan $1 \%$.

Sesuai dengan Peraturan Pemerintah No. 54 Tahun 2005 tentang pinjaman Daerah, bahwa nilai debt service coverage ratio (DSCR) yang ditentukan oleh PP No. 54 Tahun 2005, tentang Pinjaman Daerah, yang nilainya harus lebih besar atau sama dengan 2,5 sehingga jumlah pinjaman harus diturunkan lagi dari jumlah maksimum, agar angsuran pokok menjadi lebih kecil dengan jumlah dana netto tetap, atau dengan menggunakan alternative lain yaitu memperpanjang jangka waktu pengembalian, agar angsuran pokok menjadi lebih kecil dengan jumlah dana netto tetap, atau dengan menggunakan alternatif lain yaitu memperpanjang jangka waktu pengembalian.

Dari simulasi di atas dapat di lihat pada tahun 2006 dan 2007 Pemerintah Daerah Provinsi Lampung masih belum mampu melaksanakan pinjaman sebesar pada batas maksimum pinjaman karena dari nilai debt service coverage ratio (DSCR) yang didapat masing-masing hanya sebesar -0,29 dan 0,67 sedangkan batas maksimal nilai debt service coverage ratio (DSCR) yang ditentukan oleh Peraturan pemerintah Nomor 54 Tahun 2005, tentang Pinjaman Daerah adalah lebih besar atau sama dengan 2,5. Sebagai alternatif yang paling aman adalah jumlah pinjaman diturunkan, selain angsuran yang harus dibayar tidak terlalu besar, jangka waktu pengembalian tidak terlalu lama.

\section{Jumlah Pengembalian Pinjaman Daerah tahun 2005-2007}

Berdasarkan hasil perhitungan batas maksimum pinjaman dan debt service coverage ratio kemampuan pinjaman Pemerintah Daerah Provinsi Lampung sudah diketahui dari tahun 2005-2006 seperti terlihat pada tabel 12. 
Tabel 12

Pinjaman yang Dapat Dilakukan

(Lama Pinjaman 5 tahun, Bunga Bank 10\%, Biaya Komitmen 1\%)

2005-2007

\begin{tabular}{|c|c|c|c|c|c|}
\hline Tahun & $\begin{array}{c}\text { Dana Netto } \\
(\mathbf{R p})\end{array}$ & DSCR & $\begin{array}{c}\text { Besar Pokok } \\
\text { Pinjaman (Rp) }\end{array}$ & APBDt-1 & \% \\
\hline 2005 & 353.098 .245 .047 & 2,5 & 492.874 .331 .818 & 1.045 .903 .177 .788 & 47 \\
\hline 2006 & $(46.107 .831 .912)$ & 2,5 & - & 1.294 .948 .833 .024 & - \\
\hline 2007 & 130.067 .443 .897 & 2,5 & 192.291 .709 .058 & 1.361 .478 .457 .164 & 25 \\
\hline Rata-rata & $\mathbf{1 4 5 . 6 8 5 . 9 5 2 . 3 4 4}$ & $\mathbf{2 , 5}$ & $\mathbf{3 4 2 . 5 8 3 . 0 2 0 . 4 3 8}$ & $\mathbf{1 . 2 3 4 . 1 1 0 . 1 5 5 . 9 9 2}$ & $\mathbf{3 6}$ \\
\hline
\end{tabular}

Dengan menggunakan suku bunga sebesar $10 \%$ dan biaya rekomendasi $1 \%$ setiap tahun dan dikembalikan selama lima tahun dengan pokok pinjaman sebesar pada tabel 4.8 Pemerintah Daerah Provinsi Lampung harus mengembalikan pokok dan bunga sebagai berikut. Pinjaman Pemerintah Daerah Provinsi Lampung pada tahun 2005 sebesar Rp. 492.874.331.818,- sehingga jumlah yang harus dikembalikan selama 5 (lima) tahun sebesar Rp. 492.874.331.818,- x $(1,11)^{5}=$ Rp. 492.874.331.818,- x 1,685 = Rp.830.493.249.113,waktu pengembalian 2006-2011. Untuk tahun 2006 - 2007 dapat dilihat pada tabel 13.

Tabel 13

Jumlah Pokok Pinjaman dan Jumlah Pengembalian Pinjaman

Pemda Provinsi Lampung 2005 s/d 2007

\begin{tabular}{|c|c|c|c|}
\hline Tahun & $\begin{array}{c}\text { Pokok Pinjaman } \\
\text { (Rp) }\end{array}$ & $\begin{array}{c}\text { Suku Bunga } \\
(\mathbf{1 + 1 1 \% )}\end{array}$ & $\begin{array}{c}\text { Jumlah Pengembalian } \\
\text { (Pokok + Bunga) }\end{array}$ \\
\hline 2005 & 492.874 .331 .818 & 1,685 & 830.493 .249 .113 \\
\hline 2006 & - & 1,685 & - \\
\hline 2007 & 192.291 .709 .058 & 1,685 & 324.011 .529 .763 \\
\hline Rata-rata & $\mathbf{3 4 2 . 5 8 3 . 0 2 0 . 4 3 8}$ & - & $\mathbf{5 7 7 . 2 5 2 . 3 8 9 . 4 3 8}$ \\
\hline
\end{tabular}

Keterangan : $\mathrm{F}=\mathrm{P}(1+\mathrm{i})^{\mathrm{n}}$

$\mathrm{F}$ adalah jumlah pinjaman yang harus dikembalikan, $\mathrm{P}$ adalah pokok pinjaman, $\mathrm{i}$ (11\%) tingkat suku bunga bank dan biaya komitmen, dan $\mathrm{n}$ (5 tahun) adalah lama tahun pengembalian. Tabel 4.8 menggambarkan bahwa Pemerintah Daerah melakukan pinjaman pada tahun 2005 pokok pinjaman sebesar Rp.492.874.331.818,- maka jumlah yang harus dikembalikan kepada kreditur sebesar Rp.830.493.249.113,-. Pada tahun 2006 Pemerintah Daerah tidak dapat melakukan pinjaman karena dana neto pada tahun 2006 mengalami defisit. Pada tahun 2007 pokok pinjaman sebesar Rp.192.291.709.058,- maka dikembalikan sebesar Rp. 324.011.529.763,-. 


\section{Batas Maksimum Pinjaman (BMP) tahun 2008 - 2010}

Tabel 14

Jumlah Maksimum Pinjaman Pemerintah Daerah Provinsi Lampung

$2008-2010$

\begin{tabular}{|c|c|c|c|}
\hline Tahun & $\begin{array}{c}\text { Pokok Pinjaman } \\
(\mathbf{R p})\end{array}$ & $\begin{array}{c}\text { Suku Bunga } \\
(\mathbf{1 + 1 1 \%})^{\mathbf{5}}\end{array}$ & $\begin{array}{c}\text { Jumlah Pengembalian } \\
\text { (Pokok + Bunga) }\end{array}$ \\
\hline 2008 & 830.493 .249 .113 & 1,685 & 1.399 .381 .124 .755 \\
\hline 2009 & - & 1,685 & - \\
\hline 2010 & 324.011 .529 .763 & 1,685 & 545.959 .427 .651 \\
\hline Rata-rata & $\mathbf{5 7 7 . 2 5 2 . 3 8 9 . 4 3 8}$ & - & $\mathbf{9 7 2 . 6 7 0 . 2 7 6 . 2 0 3}$ \\
\hline
\end{tabular}

Untuk menentukan jumlah maksimum pinjaman pada tahun 2008-2010 Pemerintah Daerah Provinsi Lampung dapat ditentukan dari nilai sekarang (present value) jumlah pokok pinjaman pada tahun 2005-2007 yang telah dikembalikan pada pemberi pinjaman dengan menggunakan penghitungan bunga bank majemuk dengan ketentuan suku bunga bank dan biaya komitmen (r) $11 \%$ dan jangka waktu(n) 5 tahun, perhitungan ini digunakan untuk menghitung suatu pinjaman yang diserahkan pada saat melakukan pinjaman tahun awal, dan berapa besar yang akan diterima dikemudian (nilai kemudian) setelah diberikan bunga setiap akhir tahun yaitu sebesar pada tabel 14 .

\section{KESIMPULAN DAN SARAN}

\section{Kesimpulan}

Dari hasil pengolahan dan analisis data yang diuraikan pada bab IV, maka dapat disimpulkan sebagai berikut :

1. Berdasarkan hasil perhitungan yang mengacu pada Peraturan Pemerintah Nomor 54 Tahun 2005 tentang Pinjaman Daerah bahwa Pemerintah Daerah Provinsi Lampung dari tahun 2005-2007 mempunyai Batas Maksimum Pinjaman atau 60\% penerimaan umum APBD tahun sebelumnya rata-rata sebesar Rp.632.461.846.102,- dan batas maksimum pinjaman ini untuk jangka waktu 5 (lima) tahun, tingkat suku bunga bank sebesar 10\%, dan biaya komitmen 1\% tidak dapat dilakukan, karena nilai DSCR yang dihasilkan tidak mencapai sebesar 2,5 atau lebih.

2. Untuk mencapai nilai debt service coverage ratio (DSCR) sebesar atau sama dengan 2,5 dengan jangka waktu 5 (lima) tahun, bunga bank 10\%, dan biaya komitmen $1 \%$ pinjaman yang dapat dilakukan hanya sebesar rata-rata Rp.342.583.020.438,- atau sebesar 36\% dari penerimaan umum APBDt-1 pada tahun 2005-2007.

3. Berdasarkan penghitungan yang dilakukan oleh Pemerintah Daerah Provinsi Lampung untuk melakukan pinjaman dalam jangka waktu 5 (lima) tahun, bunga 10\%, dan biaya komitmen 1\% dengan menggunakan bunga majemuk pada tahun 2008-2010 rata-rata sebesar Rp.577.252.389.438,- sehingga jumlah yang harus dikembalikan selama pada tahun tersebut adalah sebesar Rp.972.670.276.203,-. 


\section{Saran}

Berdasarkan hasil kesimpulan di atas, dapat diberikan beberapa rekomendasi sebagai berikut :

1. Setelah dilakukan penghitungan terhadap kemampuan batas maksimum pinjaman, sebaiknya Pemerintah Daerah Provinsi Lampung dalam melakukan pinjaman tidak mengambil batas maksimum, karena harus memperhitungkan dana neto yang tersedia untuk membayar angsuran dimasa akan datang, Pemerintah Daerah disarankan melakukan pinjaman sebesar 35\% saja dari penerimaan umum APBD tahun sebelumnya, hal ini bertujuan untuk mencapai nilai DSCR lebih dari 2,5, dengan asumsi jangka waktu pengembalian paling lama 5 (lima) tahun dan tingkat suku bunga bank $10 \%$ dan biaya komitmen $1 \%$.

2. Apabila Pemerintah Daerah melakukan pinjaman sebaiknya jangka waktu pinjaman tidak melebihi masa jabatan kepala daerah yaitu maksimal 5 (lima) tahun, sehingga tidak akan membebani pejabat kepala daerah yang akan datang dan apabila diperlukan dibuat dalam Peraturan Daerah agar menjadi pedoman bagi pejabat berikutnya dalam melakukan pinjaman daerah.

\section{DAFTAR PUSTAKA}

Bastian, Indra, dan Gatot Soepriyanto, Sistem Akuntansi Sektor Publik Konsep Untuk Pemerintah Daerah, Salemba Empat, Jakarta, 2003

Davey, K.J, Pembiayaan Pemerintah Daerah, Praktek-praktek Internasional dan relevansinya Bagi Dunia Ketiga (terjemahan Aminullah), UI-Press, Jakarta, 1988

Halim, Abdul, Akuntansi Dan Pengendalian Keuangan Daerah, AMP YKPN, Yogyakarta, 2002

Pemerintah RI, Peraturan Menteri Keuangan Nomor 147/PMK.07/2006 tentang Tatacara Penerbitan, Petanggungjawaban, dan Publikasi Informasi Obligasi Daerah, Jakarta, 2006

Pemerintah RI, Peraturan Menteri Keuangan Nomor 45/PMK.02/2006 tentang Pedoman Pelaksanaan dan Mekanisme Pemantauan Defisit Anggaran Pendapatan dan Belanja Daerah dan Pinjaman Daerah, Jakarta 2006

Pemerintah RI, Peraturan Menteri Negara Perencanaan Pembangunan Nasional/Kepala Bappenas No.005/M.PPN/06/2006 tentang Tatacara Perencanaan dan Pengajuan Usulan serta Penilaian Kegiatan yang Dibiayai dari Pinjaman dan/atau Hibah Luar Negeri, Jakarta, 2006

Pemerintah RI, Peraturan Pemerintah Nomor 2 Tahun 2006 tentang Tata Cara Pengadaan Pinjaman dan/atau Penerimaan Hibah serta Penerusan Pinjaman dan/atau Hibah Luar Negeri, Jakarta, 2006

Pemerintah RI, Peraturan Pemerintah Nomor 54 Tahun 2005 tentang Pinjaman Daerah, Jakarta, 2005

Pemerintah RI, Undang-undang Nomor 1 Tahun 2004 tentang Perbendaharaan Negara, Jakarta, 2004 
Pemerintah RI, Undang-undang Nomor 17 Tahun 2003 tentang Keuangan Negara, Jakarta, 2003

Pemerintah RI, Undang-undang Nomor 25 Tahun 2004 tentang Sistem Perencanaan Pembangunan Nasioanal, Jakarta 2004

Pemerintah RI, Undang-undang Nomor 32 Tahun 2004 tentang Pemerintah Daerah, Jakarta, 2004

Pemerintah RI, Undang-undang Nomor 33 Tahun 2004 tentang Perimbangan Keuangan Antara Pemerintah Pusat dan Pemerintah Daerah, Jakarta, 2004

Sartono, Agus, Manajemen Keuangan, BPFE, Yogyakarta, 1997

Yani, Ahmad, Hubungan Keuangan Antara Pemerintah Pusat dan Daerah di Indonesia, Rajawali Pers, Jakarta , 2002 
Sengaja dikosongkan 